\title{
A meta-analysis of randomized trials of telmisartan versus losartan for reduction of ambulatory blood pressure
}

\author{
Hisato Takagi, Masao Niwa, Yusuke Mizuno, Shin-nosuke Goto and Takuya Umemoto for the ALICE \\ (All-Literature Investigation of Cardiovascular Evidence) Group
}

A previous meta-analysis of a few randomized controlled trials (RCTs) suggests a significant reduction in ambulatory blood pressure (BP) with telmisartan as compared with losartan monotherapy. We performed an updated meta-analysis of RCTs of telmisartan versus losartan therapy for reduction of ambulatory BP in patients with hypertension. MEDLINE, EMBASE and the Cochrane Central Register of Controlled Trials were searched through July 2012 using PubMed and OVID. Eligible studies were RCTs of telmisartan versus valsartan therapy enrolling individuals with hypertension and reporting ambulatory BP as an outcome. For each study, data regarding changes from baseline in ambulatory ( $24 \mathrm{~h}$, last $6 \mathrm{~h}$, morning, daytime and nighttime) BP in both the telmisartan and losartan groups were used to generate mean differences (MDs) and $95 \%$ confidence intervals (Cls). Of 34 potentially relevant articles screened initially, 9 reports of RCTs enrolling a total of 2409 patients with hypertension were identified and included. Pooled analysis suggested significant reductions in all of 24-h (MD of systolic/ diastolic BP, $-2.09 /-1.57 \mathrm{~mm} \mathrm{Hg} ; 95 \% \mathrm{Cl},-3.39 /-2.32$ to $-0.79 /-0.82 \mathrm{~mm} \mathrm{Hg})$, last 6-h $(-2.96 /-2.15 \mathrm{~mm} \mathrm{Hg} ;-3.80 /-2.72$ to $-2.13 /-1.59 \mathrm{~mm} \mathrm{Hg})$, morning $(-2.71 /-2.37 \mathrm{~mm} \mathrm{Hg} ;-3.73 /-3.33$ to $-1.69 /-1.41 \mathrm{~mm} \mathrm{Hg})$, daytime $(-1.74 /-1.73 \mathrm{~mm} \mathrm{Hg}$; $-3.27 /-2.84$ to $-0.20 /-0.62 \mathrm{~mm} \mathrm{Hg})$ and nighttime BP $(-2.70 /-2.08 \mathrm{~mm} \mathrm{Hg} ;-4.07 /-3.24$ to $-1.33 /-0.92 \mathrm{~mm} \mathrm{Hg})$ among patients randomized to telmisartan versus losartan therapy. In conclusion, telmisartan therapy appears to reduce ambulatory BP more than losartan therapy in patients with hypertension.

Hypertension Research (2013) 36, 959-966; doi:10.1038/hr.2013.78; published online 15 August 2013

Keywords: ambulatory blood pressure; hypertension; losartan; meta-analysis; telmisartan

\section{INTRODUCTION}

In the most recent (2011) recommendations (updating the 2004 and 2006 clinical guidelines) from the NICE (National Institute for Health and Clinical Excellence) on the management of hypertension, ${ }^{1}$ ambulatory blood pressure (BP) monitoring should be used to confirm the diagnosis of hypertension if the clinic BP is 140/ $90 \mathrm{~mm} \mathrm{Hg}$ or higher. Further, for people identified as having a 'white coat effect' (that is, a discrepancy of more than $20 / 10 \mathrm{~mm} \mathrm{Hg}$ between clinic and average daytime ambulatory BP (or average home $\mathrm{BP})$ measurements at the time of diagnosis), ambulatory (or home) BP monitoring as an adjunct to clinic BP measurements should be considered to monitor the response to antihypertensive treatment with lifestyle modification or drugs. ${ }^{1}$ Telmisartan is the longest acting angiotensin II type 1 receptor blocker currently available, and its mean elimination half-life is approximately $24 \mathrm{~h}$ in patients with mild-to-moderate hypertension who receive 20 to $160 \mathrm{mg}$ per day telmisartan for 4 weeks. ${ }^{2}$ Thus, telmisartan would be expected to reduce ambulatory $\mathrm{BP}$ more than the other angiotensin II type 1 receptor blockers. Indeed, a previous meta-analysis ${ }^{3}$ suggests a significant reduction in ambulatory BP with telmisartan as compared with losartan (classified as shorter-acting) monotherapy. The results were, however, based on data pooled from a few randomized controlled trials (RCTs). Therefore, the appropriate role of telmisartan by comparison with losartan therapy on ambulatory BP in the hypertensive population remains unclear. We performed an updated meta-analysis of RCTs of telmisartan versus losartan therapy for reduction of ambulatory BP in patients with hypertension.

\section{METHODS}

Search strategy

All RCTs of telmisartan versus losartan therapy enrolling patients with hypertension and reporting ambulatory BP were identified using a two-level search strategy. First, public domain databases including MEDLINE, EMBASE and the Cochrane Central Register of Controlled Trials were searched using Web-based search engines (PubMed, OVID). Second, relevant studies were identified through a manual search of secondary sources including references of initially identified articles and a search of reviews and commentaries. All references were downloaded for consolidation, elimination of duplicates and 


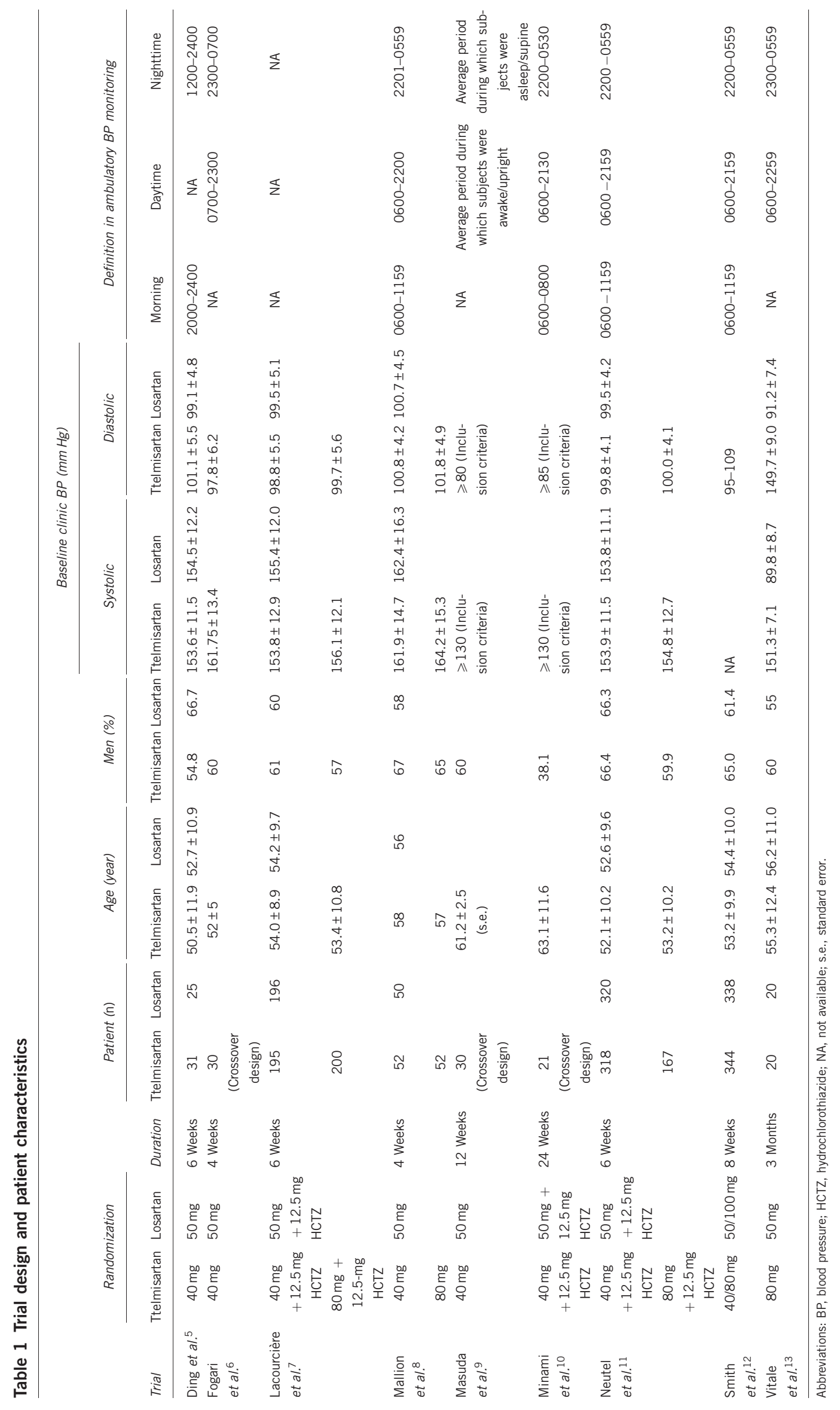


further analysis. The databases were searched through July 2012. Keywords included ambulatory, 24 hour, or $24 \mathrm{~h}$; telmisartan; losartan; randomized, randomised, randomly, or randomization.

Study selection and data abstraction

Studies considered for inclusion met the following criteria: the design was a RCT (including a quasi-randomized crossover design study); the study population was patients with hypertension; patients were randomly assigned to telmisartan versus losartan therapy (not only monotherapy but also combination therapy); main outcomes included ambulatory BP; and the results were published in English-language peer-reviewed journals. Data regarding detailed inclusion criteria, duration of treatment, changes from baseline to final ambulatory BP were abstracted (as available) from each individual study.

\section{Statistical analysis}

We conducted a meta-analysis of summary statistics from the individual trials because detailed, patient-level data were not available for all trials. For each study, data regarding changes from baseline in ambulatory $(24 \mathrm{~h}$, last $6 \mathrm{~h}$, morning, daytime and nighttime as defined by the authors of each individual study) BP in both the telmisartan and losartan groups were used to generate mean differences (MDs) and 95\% confidence intervals (CIs). When a MD itself of BP changes in the two groups was reported, we directly extracted it with its 95\% CI. Missing standard deviations were imputed according to the Cochrane Handbook. ${ }^{4}$ Study-specific estimates were combined in the random-effects model for its conservative summary estimate and incorporating both between and within study variance. All analyses were conducted using Review Manager version 5.1 (Nordic Cochrane Centre, Copenhagen, Denmark).

\section{RESULTS}

Of 34 potentially relevant papers screened initially, we excluded 9 non-original articles, 13 irrelevant-design studies and 3 duplicate publications. Nine reports of eligible RCTs ${ }^{5-13}$ of telmisartan versus losartan therapy enrolling a total of 2409 patients with hypertension and reporting ambulatory BP were identified and included (Table 1). Of these studies, six studies provided data on effectiveness for the comparison between telmisartan and losartan in monotherapy, ${ }^{5,6,8,9,12,13}$ and three studies compared these two agents in fixed-dose combination with $12.5 \mathrm{mg}$ hydrochlorothiazide. ${ }^{7,10,11}$ Methodological quality of the trials by using the scoring system developed by Jadad et al. ${ }^{14}$ and adverse events are summarized in Tables 2 and 3 , respectively.

Pooled analysis demonstrated a statistically significant reduction in changes (from baseline to final) of all of 24-h (MD of systolic BP, $-2.09 \mathrm{~mm} \mathrm{Hg} ; 95 \% \mathrm{CI},-3.39$ to $-0.79 \mathrm{~mm} \mathrm{Hg} ; P$ for effect $=0.002$; $P$ for heterogeneity $<0.0001$; Figure $1 \mathrm{a} ; \mathrm{MD}$ of diastolic BP, $-1.57 \mathrm{~mm} \mathrm{Hg}$; $95 \% \mathrm{CI},-2.32$ to $-0.82 \mathrm{~mm} \mathrm{Hg} ; P$ for effect $<0.0001$; $P$ for heterogeneity $=0.004$; Figure $1 \mathrm{~b}$ ), last $6-\mathrm{h}$ (MD of systolic BP, $-2.96 \mathrm{~mm} \mathrm{Hg} ; 95 \% \mathrm{CI},-3.80$ to $-2.13 \mathrm{~mm} \mathrm{Hg}$; $P$ for effect $<0.00001$; $P$ for heterogeneity $=0.69$; Figure $2 \mathrm{a}$; MD of diastolic BP, $-2.15 \mathrm{~mm}$ $\mathrm{Hg}$; $95 \% \mathrm{CI},-2.72$ to $-1.59 \mathrm{~mm} \mathrm{Hg} ; P$ for effect $<0.00001$; $P$ for heterogeneity $=0.61$; Figure $2 \mathrm{~b}$ ), morning ( $\mathrm{MD}$ of systolic $\mathrm{BP}$, $-2.71 \mathrm{~mm} \mathrm{Hg} ; 95 \% \mathrm{CI},-3.73$ to $-1.69 \mathrm{~mm} \mathrm{Hg} ; \quad P$ for effect $<0.00001 ; P$ for heterogeneity $=0.39$; Figure $3 \mathrm{a}$; $\mathrm{MD}$ of diastolic BP, $-2.37 \mathrm{~mm} \mathrm{Hg} ; \quad 95 \% \quad \mathrm{CI},-3.33$ to $-1.41 \mathrm{~mm} \mathrm{Hg} ; \quad P$ for effect $<0.00001 ; P$ for heterogeneity $=0.15$; Figure $3 \mathrm{~b}$ ), daytime (MD of systolic BP, $-1.74 \mathrm{~mm} \mathrm{Hg} ; 95 \% \mathrm{CI},-3.27$ to $-0.20 \mathrm{~mm} \mathrm{Hg}$; $P$ for effect $=0.03$; $P$ for heterogeneity $<0.00001$; Figure $4 \mathrm{a}$; MD of diastolic BP, $-1.73 \mathrm{~mm} \mathrm{Hg}$; 95\% CI, -2.84 to $-0.62 \mathrm{~mm} \mathrm{Hg}$; $P$ for effect $=0.002 ; P$ for heterogeneity $<0.00001$; Figure $4 \mathrm{~b}$ ) and nighttime BP (MD of systolic BP, $-2.70 \mathrm{~mm} \mathrm{Hg} ; 95 \% \mathrm{CI},-4.07$ to $-1.33 \mathrm{~mm} \mathrm{Hg} ; \quad P$ for effect $=0.0001 ; P$ for heterogeneity $=0.0003$; Figure $5 \mathrm{a}$; $\mathrm{MD}$ of diastolic $\mathrm{BP},-2.08 \mathrm{~mm} \mathrm{Hg} ; 95 \% \mathrm{CI},-3.24$ to
Table 2 Methodological quality of trials

\begin{tabular}{|c|c|c|c|c|c|c|c|}
\hline \multirow[b]{2}{*}{ Trial } & \multirow[b]{2}{*}{$\begin{array}{c}\text { Allocation } \\
\text { concealment }\end{array}$} & \multicolumn{3}{|c|}{ Blinding } & \multirow[b]{2}{*}{$I T T$} & \multirow[b]{2}{*}{$\begin{array}{c}\text { Lost to } \\
\text { follow-up (\%) }\end{array}$} & \multirow[b]{2}{*}{$\begin{array}{l}\text { Quailty } \\
\text { score }\end{array}$} \\
\hline & & Participants & $\begin{array}{l}\text { Investi- } \\
\text { gators }\end{array}$ & $\begin{array}{l}\text { Outcomes } \\
\text { assessors }\end{array}$ & & & \\
\hline Ding et al. ${ }^{5}$ & Unclear & Yes & Yes & Yes & Yes & 8 & 4 \\
\hline Fogari et al. ${ }^{6}$ & Unclear & Yes & Yes & Yes & UA & 0 & 3 \\
\hline $\begin{array}{l}\text { Lacourcière } \\
\text { et al. }{ }^{7}\end{array}$ & Unclear & No & No & Yes & Yes & 1 & 2 \\
\hline $\begin{array}{l}\text { Mallion } \\
\text { et al. }{ }^{8}\end{array}$ & Unclear & Yes & Yes & Yes & Yes & 8 & 4 \\
\hline $\begin{array}{l}\text { Masuda } \\
\text { et al. }{ }^{9}\end{array}$ & Unclear & UA & UA & UA & UA & UA & 0 \\
\hline $\begin{array}{l}\text { Minami } \\
\text { et al. }{ }^{10}\end{array}$ & Unclear & UA & UA & UA & UA & 0 & 1 \\
\hline $\begin{array}{l}\text { Neutel } \\
\text { et al. }{ }^{11}\end{array}$ & Unclear & No & No & Yes & UA & UA & 1 \\
\hline Smith et al. ${ }^{12}$ & Unclear & Yes & Yes & Yes & Yes & NA & 3 \\
\hline Vitale et al. ${ }^{13}$ & Adequate & Yes & Yes & Yes & UA & UA & 3 \\
\hline
\end{tabular}

Abbreviations: ITT, intention to treat analysis; NA, not available; UA, unable to assess.

Table 3 Adverse events and withdrawals

\begin{tabular}{|c|c|c|c|}
\hline \multirow[b]{3}{*}{ Trial } & \multicolumn{3}{|c|}{ Telmisartan/losartan } \\
\hline & \multicolumn{2}{|c|}{ Adverse events } & \multirow[b]{2}{*}{ Withdrawals (n) } \\
\hline & Overall (\%) & Drug related (n) & \\
\hline Ding et al. ${ }^{5}$ & $12.9 / 13.3$ & $3 / 3$ & $0 / 1^{a}$ \\
\hline Fogari et al. ${ }^{6}$ & NA & $2 / 3$ & $0 / 0$ \\
\hline Lacourcière et al. ${ }^{7}$ & $22(18)^{b} / 14$ & $10 \%(7 \%)^{\mathrm{b} / 5 \%}$ & $3(2)^{b / 1}$ \\
\hline Mallion et al. ${ }^{8}$ & NA & NA & $1 / 5$ \\
\hline Masuda et al. ${ }^{9}$ & NA & NA & NA \\
\hline Minami et al. ${ }^{10}$ & $0 / 0$ & $0 / 0$ & $1^{c}$ \\
\hline Neutel et al. ${ }^{11}$ & NA & $4.4 \%(6.0 \%)^{\mathrm{b}} / 2.8 \%$ & $2.5 \%(0.6 \%)^{b} / 0.9 \%$ \\
\hline Smith et al. ${ }^{12}$ & $\begin{array}{l}22.8(20.2)^{\mathrm{b}} / \\
22.2(23.3)^{\mathrm{d}}\end{array}$ & NA & NA \\
\hline Vitale et al. ${ }^{13}$ & $0 / 0$ & $0 / 0$ & NA \\
\hline
\end{tabular}

Abbreviation: NA, not available.

aNot deemed to be treatment related.

b $40 \mathrm{mg}(80 \mathrm{mg})$ telmisartan.

'Because of hospitalization for the treatment of chronic hepatitis $\mathrm{C}$ (unknown group). d50 mg (100 mg) losartan.

$-0.92 \mathrm{~mm} \mathrm{Hg} ; P$ for effect $=0.0004 ; P$ for heterogeneity $<0.00001$; Figure $5 \mathrm{~b}$ ) with telmisartan relative to losartan

To assess the impact of qualitative heterogeneity in trial design and patient selection on the pooled effect estimate, we performed several sensitivity analyses for 24-h BP. First, we excluded three quasirandomized crossover design studies; $;{ }^{6,9,10}$ combing the remaining trials generated an amplified and still statistically significant result favoring telmisartan over losartan therapy for 24-h BP (MD of systolic BP, $-2.49 \mathrm{~mm} \mathrm{Hg} ; \quad 95 \% \quad \mathrm{CI},-3.39$ to $-1.58 \mathrm{~mm} \mathrm{Hg}$; $P<0.00001 ;$ MD of diastolic BP, $-1.96 \mathrm{~mm} \mathrm{Hg} ; 95 \% \mathrm{CI},-2.64$ to $-1.28 \mathrm{~mm} \mathrm{Hg} ; \quad P<0.00001)$ with no statistically significant heterogeneity ( $P=0.23$ for systolic BP; $P=0.09$ for diastolic BP). Second, we excluded three low quality-score $(0$ or 1$)$ studies. ${ }^{9-11}$ Without them, there was still a statistically significant benefit for telmisartan therapy over losartan therapy for $24 \mathrm{~h}$ BP in pooled analysis of the remaining trials (MD of systolic BP, $-2.14 \mathrm{~mm} \mathrm{Hg}$; 


\begin{tabular}{|c|c|c|c|c|c|c|}
\hline \multirow{2}{*}{ a $_{\text {Study or Subgroup }}$} & \multicolumn{2}{|c|}{$\begin{array}{cl} & \text { Mean Difference } \\
\text { Weight } & \text { IV, Random, } 95 \% \mathrm{CI}\end{array}$} & \multicolumn{4}{|c|}{$\begin{array}{c}\text { Mean Difference } \\
\text { IV, Random, } 95 \% \mathrm{CI}\end{array}$} \\
\hline & $4.2 \%$ & $-3.35[-8.80,2.10]$ & & & & \\
\hline Fogari 2002 & $14.5 \%$ & $0.70[-0.24,1.64]$ & & & - & \\
\hline Lacourcière $2003,40 \mathrm{mg}$ & $11.6 \%$ & $-2.05[-4.00,-0.10]$ & & & & \\
\hline Lacourcière $2003,80 \mathrm{mg}$ & $11.6 \%$ & $-3.45[-5.40,-1.50]$ & & & & \\
\hline Mallion 1999, $40 \mathrm{mg}$ & $7.1 \%$ & $-3.50[-7.10,0.10]$ & & & & \\
\hline Mallion 1999, $80 \mathrm{mg}$ & $7.1 \%$ & $-5.30[-8.90,-1.70]$ & & & & \\
\hline Masuda 2009 & $3.7 \%$ & $-3.00[-8.96,2.96]$ & & & & \\
\hline Minami 2009 & $3.2 \%$ & $2.30[-4.23,8.83]$ & & & & \\
\hline Neutel $2005,40 \mathrm{mg}$ & $12.5 \%$ & $-1.70[-3.35,-0.05]$ & & & & \\
\hline Neutel $2005,80 \mathrm{mg}$ & $11.5 \%$ & $-3.50[-5.49,-1.51]$ & & 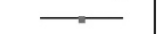 & & \\
\hline Smith 2003 & $13.1 \%$ & $-1.05[-2.50,0.40]$ & & & & \\
\hline Total $(95 \% \mathrm{Cl})$ & $100.0 \%$ & $-2.09[-3.39,-0.79]$ & & & & \\
\hline \multirow{2}{*}{\multicolumn{3}{|c|}{$\begin{array}{l}\text { Heterogeneity: } \mathrm{Tau}^{2}=2.82 ; \mathrm{Chi}^{2}=35.75, \mathrm{df}=10(\mathrm{P}<0.0001) ; \mathrm{I}^{2}=72 \% \\
\text { Test for overall effect: } Z=3.15(\mathrm{P}=0.002)\end{array}$}} & -10 & -5 & 5 & 10 \\
\hline & & & \multicolumn{4}{|c|}{ Favours telmisartan Favours losartan } \\
\hline btudy or Subgroup & Weight & $\begin{array}{l}\text { Mean Difference } \\
\text { IV, Random, } 95 \% \mathrm{Cl}\end{array}$ & \multicolumn{4}{|c|}{$\begin{array}{c}\text { Mean Difference } \\
\text { IV, Random, } 95 \% \mathrm{Cl}\end{array}$} \\
\hline Ding 2004 & $4.0 \%$ & $-4.20[-7.50,-0.90]$ & & 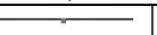 & & \\
\hline Fogari 2002 & $13.7 \%$ & $-0.10[-1.04,0.84]$ & & & & \\
\hline Lacourcière $2003,40 \mathrm{mg}$ & $13.3 \%$ & $-1.30[-2.30,-0.30]$ & & $\rightarrow$ & & \\
\hline Lacourcière $2003,80 \mathrm{mg}$ & $11.4 \%$ & $-2.30[-3.60,-1.00]$ & & 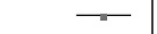 & & \\
\hline Mallion $1999,40 \mathrm{mg}$ & $6.9 \%$ & $-2.50[-4.72,-0.28]$ & & & & \\
\hline Mallion $1999,80 \mathrm{mg}$ & $6.9 \%$ & $-3.50[-5.72,-1.28]$ & & 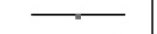 & & \\
\hline Masuda 2009 & $5.8 \%$ & $1.00[-1.53,3.53]$ & & & & \\
\hline Minami 2009 & $2.0 \%$ & $0.20[-4.79,5.19]$ & & & & \\
\hline Neutel 2005, $40 \mathrm{mg}$ & $12.4 \%$ & $-1.40[-2.54,-0.26]$ & & 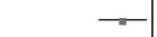 & & \\
\hline Neutel $2005,80 \mathrm{mg}$ & $10.3 \%$ & $-3.00[-4.50,-1.50]$ & & 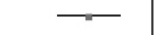 & & \\
\hline Smith 2003 & $13.3 \%$ & $-0.90[-1.90,0.10]$ & & & & \\
\hline Total $(95 \% \mathrm{Cl})$ & $100.0 \%$ & $-1.57[-2.32,-0.82]$ & & & & \\
\hline $\begin{array}{l}\text { Heterogeneity: } \mathrm{Tau}^{2}=0.8 \\
\text { Test for overall effect: } \mathrm{Z}=\end{array}$ & $\begin{array}{l}; \mathrm{Chi}^{2}=2 \\
4.11(\mathrm{P}<\end{array}$ & $\begin{array}{l}5.49, \mathrm{df}=10(P=0.004) ; I^{2}=61 \% \\
0.0001)\end{array}$ & -1 & -5 & 5 & 10 \\
\hline
\end{tabular}

Figure 1 Forest plot of 24-h systolic (a) and diastolic (b) blood pressure among patients with hypertension randomized to telmisartan versus losartan therapy. $\mathrm{Cl}$, confidence interval; IV, inverse variance. A full color version of this figure is available at the Hypertension Research journal online.

\begin{tabular}{|c|c|c|c|c|c|c|}
\hline \multirow{2}{*}{$\begin{array}{l}\text { a } \\
\text { Study or Subgroup } \\
\text { Ding } 2004\end{array}$} & \multirow{2}{*}{$\begin{aligned} \text { Weight } \\
1.4 \%\end{aligned}$} & \multirow{2}{*}{$\begin{array}{l}\text { Mean Difference } \\
\text { IV, Random, 95\% Cl } \\
-4.15[-11.10,2.80]\end{array}$} & \multicolumn{4}{|c|}{$\begin{array}{l}\text { Mean Difference } \\
\text { IV, Random, } 95 \% \mathrm{CI}\end{array}$} \\
\hline & & & 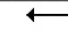 & & & \\
\hline Lacourcière $2003,40 \mathrm{mg}$ & $14.5 \%$ & $-2.50[-4.70,-0.30]$ & & & & \\
\hline Lacourcière $2003,80 \mathrm{mg}$ & $15.1 \%$ & $-3.35[-5.50,-1.20]$ & & & & \\
\hline Mallion 1999, 40 mg & $4.0 \%$ & $-4.70[-8.86,-0.54]$ & & & & \\
\hline Mallion $1999,80 \mathrm{mg}$ & $4.0 \%$ & $-6.20[-10.36,-2.04]$ & 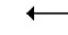 & & & \\
\hline Neutel $2005,40 \mathrm{mg}$ & $20.4 \%$ & $-2.65[-4.50,-0.80]$ & & & & \\
\hline Neutel $2005,80 \mathrm{mg}$ & $15.1 \%$ & $-3.45[-5.60,-1.30]$ & & & & \\
\hline Smith 2003 & $25.3 \%$ & $-2.10[-3.76,-0.44]$ & & & & \\
\hline Total $(95 \% \mathrm{Cl})$ & $100.0 \%$ & $-2.96[-3.80,-2.13]$ & & & & \\
\hline \multirow{2}{*}{\multicolumn{3}{|c|}{$\begin{array}{l}\text { Heterogeneity: } \mathrm{Tau}^{2}=0.00 ; \mathrm{Chi}^{2}=4.75, \mathrm{df}=7(\mathrm{P}=0.69) ; \mathrm{I}^{2}=0 \% \\
\text { Test for overall effect: } \mathrm{Z}=6.95(\mathrm{P}<0.00001)\end{array}$}} & -10 & -5 & 5 & 10 \\
\hline & & & \multicolumn{4}{|c|}{ Favours telmisartan Favours losartan } \\
\hline Study or Subgroup & Weight & $\begin{array}{l}\text { Mean Difference } \\
\text { IV, Random, } 95 \% \mathrm{CI}\end{array}$ & & $\begin{array}{l}\text { Mean Dif } \\
\text { IV, Randon }\end{array}$ & $\begin{array}{l}\text { ifference } \\
\text { m, } 95 \% \mathrm{Cl}\end{array}$ & \\
\hline Ding 2004 & $1.4 \%$ & $-5.15[-9.90,-0.40]$ & & & & \\
\hline Lacourcière $2003,40 \mathrm{mg}$ & $15.2 \%$ & $-1.75[-3.20,-0.30]$ & & $\rightarrow$ & & \\
\hline Lacourcière $2003,80 \mathrm{mg}$ & $15.2 \%$ & $-2.45[-3.90,-1.00]$ & & 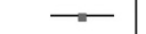 & & \\
\hline Mallion 1999, 40 mg & $4.2 \%$ & $-3.10[-5.87,-0.33]$ & & & & \\
\hline Mallion 1999, $80 \mathrm{mg}$ & $4.2 \%$ & $-3.40[-6.17,-0.63]$ & & & & \\
\hline Neutel 2005, $40 \mathrm{mg}$ & $20.5 \%$ & $-1.95[-3.20,-0.70]$ & & $-\leftarrow$ & & \\
\hline Neutel $2005,80 \mathrm{mg}$ & $13.3 \%$ & $-2.85[-4.40,-1.30]$ & & - & & \\
\hline Smith 2003 & $26.0 \%$ & $-1.50[-2.61,-0.39]$ & & -- & & \\
\hline Total $(95 \% \mathrm{Cl})$ & $100.0 \%$ & $-2.15[-2.72,-1.59]$ & & 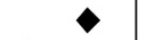 & & \\
\hline \multicolumn{3}{|c|}{$\begin{array}{l}\text { Heterogeneity: } \mathrm{Tau}^{2}=0.00 ; \mathrm{Chi}^{2}=5.42, \mathrm{df}=7(P=0.61) ; \mathrm{I}^{2}=0 \% \\
\text { Test for overall effect: } Z=7.46(P<0.00001)\end{array}$} & -10 & -5 & 0 & 10 \\
\hline
\end{tabular}

Figure 2 Forest plot of last 6-h systolic (a) and diastolic (b) blood pressure among patients with hypertension randomized to telmisartan versus losartan therapy. $\mathrm{Cl}$, confidence interval; IV, inverse variance. A full color version of this figure is available at the Hypertension Research journal online. 


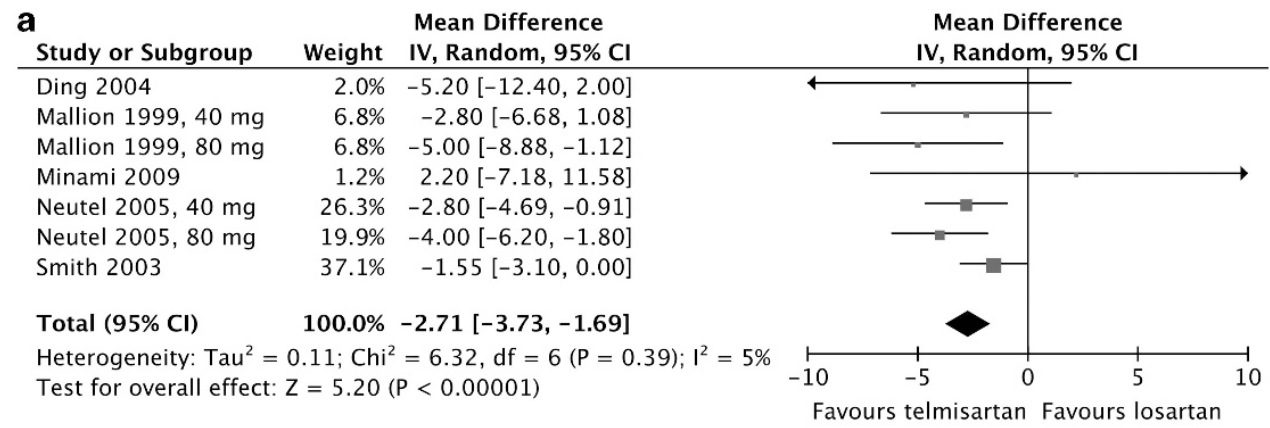

\begin{tabular}{|c|c|c|c|c|c|c|}
\hline $\mathbf{b}_{\text {Study or Subgroup }}$ & Weight & $\begin{array}{l}\text { Mean Difference } \\
\text { IV, Random, } 95 \% \mathrm{CI}\end{array}$ & \multicolumn{4}{|c|}{$\begin{array}{l}\text { Mean Difference } \\
\text { IV, Random, 95\% CI }\end{array}$} \\
\hline Ding 2004 & $3.2 \%$ & $-5.05[-10.20,0.10]$ & $\leftarrow$ & & & \\
\hline Mallion $1999,40 \mathrm{mg}$ & $11.1 \%$ & $-2.50[-4.99,-0.01]$ & & & & \\
\hline Mallion 1999, $80 \mathrm{mg}$ & $11.1 \%$ & $-3.40[-5.89,-0.91]$ & & & & \\
\hline Minami 2009 & $2.7 \%$ & $-0.30[-6.02,5.42]$ & & & & \\
\hline Neutel 2005, $40 \mathrm{mg}$ & $26.0 \%$ & $-2.40[-3.60,-1.20]$ & & $\rightarrow$ & & \\
\hline Neutel $2005,80 \mathrm{mg}$ & $17.3 \%$ & $-3.60[-5.40,-1.80]$ & & & & \\
\hline Smith 2003 & $28.7 \%$ & $-1.05[-2.10,0.00]$ & & & & \\
\hline Total $(95 \% \mathrm{Cl})$ & $100.0 \%$ & $-2.37[-3.33,-1.41]$ & & & & \\
\hline \multicolumn{3}{|c|}{$\begin{array}{l}\text { Heterogeneity: } \mathrm{Tau}^{2}=0.55 ; \mathrm{Chi}^{2}=9.53, \mathrm{df}=6(\mathrm{P}=0.15) ; \mathrm{I}^{2}=37 \% \\
\text { Test for overall effect: } \mathrm{Z}=4.83(\mathrm{P}<0.00001)\end{array}$} & $\stackrel{b}{-10}$ & -5 & 0 & 10 \\
\hline
\end{tabular}

Figure 3 Forest plot of morning systolic (a) and diastolic (b) blood pressure among patients with hypertension randomized to telmisartan versus losartan therapy. $\mathrm{Cl}$, confidence interval; IV, inverse variance. A full color version of this figure is available at the Hypertension Research journal online.

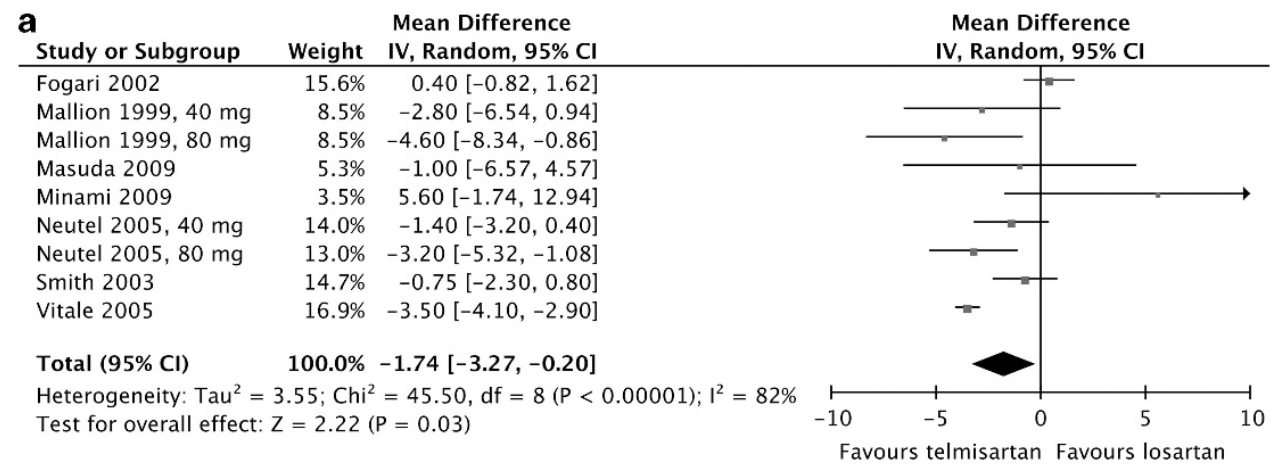

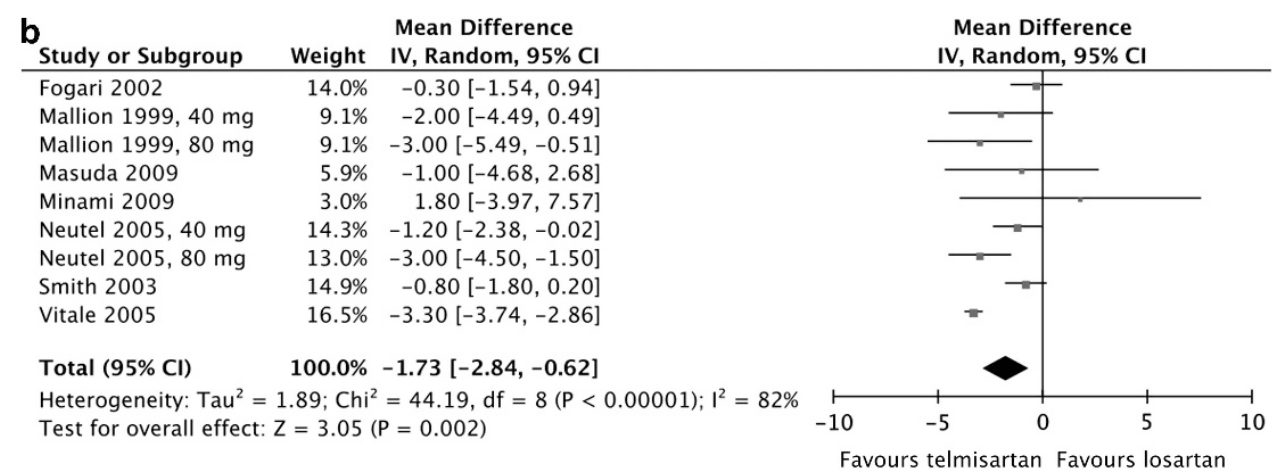

Figure 4 Forest plot of daytime systolic (a) and diastolic (b) blood pressure among patients with hypertension randomized to telmisartan versus losartan therapy. $\mathrm{Cl}$, confidence interval; IV, inverse variance. A full color version of this figure is available at the Hypertension Research journal online.

95\% CI, -3.84 to $-0.45 \mathrm{~mm} \mathrm{Hg} ; P=0.01 ; \mathrm{MD}$ of diastolic BP, $-1.66 \mathrm{~mm} \mathrm{Hg} ; 95 \% \mathrm{CI},-2.56$ to $-0.75 \mathrm{~mm} \mathrm{Hg} ; P=0.0003)$ with still statistically significant heterogeneity $(P=0.0001$ for systolic BP; $P=0.009$ for diastolic BP). Our additional search identified four RCTs ${ }^{15-18}$ of telmisartan versus valsartan therapy for the reduction of ambulatory BP. Including these valsartan-control trials in the primary meta-analysis generated an attenuated and still statistically significant result favoring telmisartan over losartan or valsartan therapy for 24-h BP (MD of systolic BP, $-1.73 \mathrm{~mm} \mathrm{Hg}$; $95 \%$ CI, -2.94 to $-0.52 \mathrm{~mm} \mathrm{Hg}$; $P$ for effect $=0.005, P$ for heterogeneity 

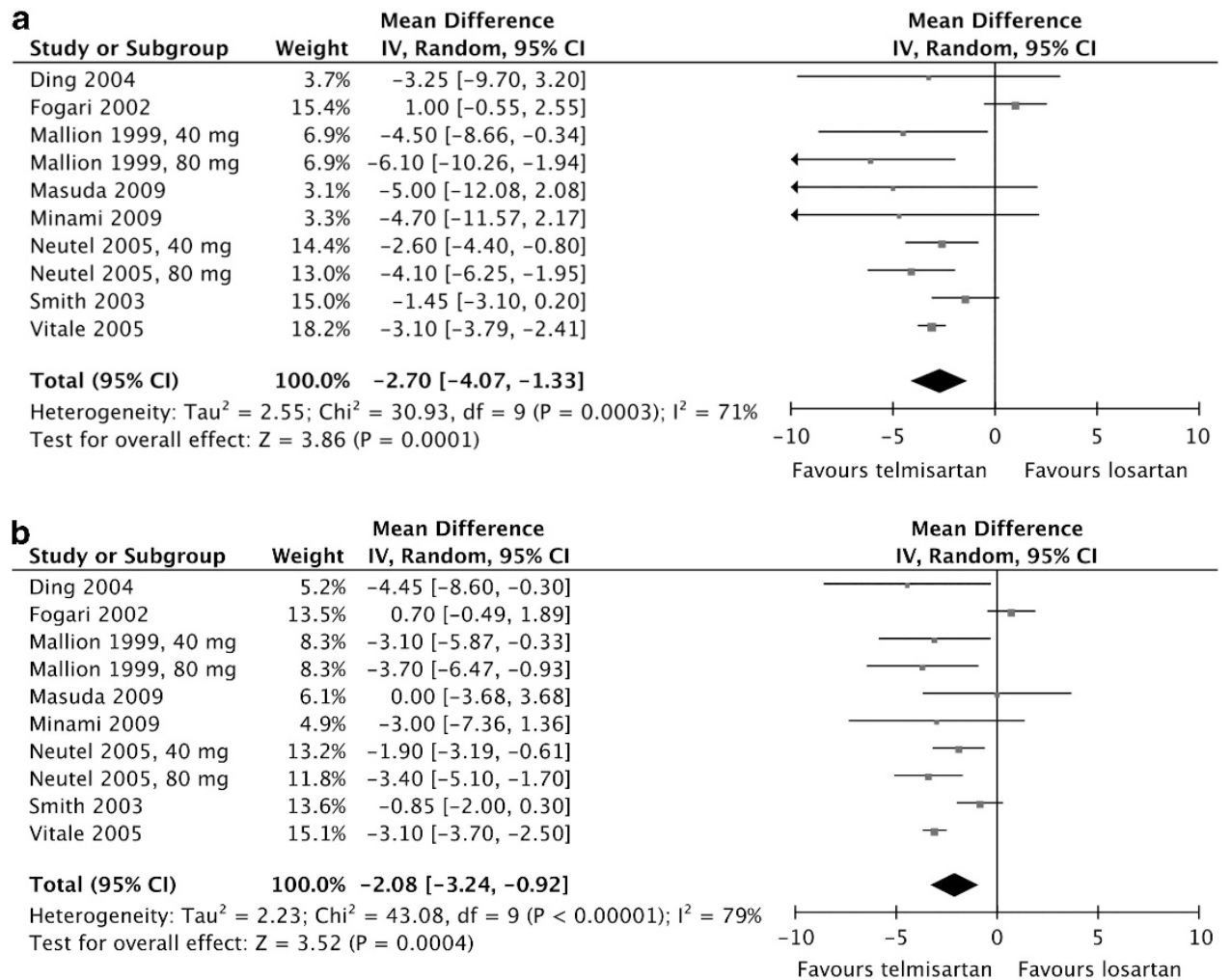

Figure 5 Forest plot of nighttime systolic (a) and diastolic (b) blood pressure among patients with hypertension randomized to telmisartan versus losartan therapy. $\mathrm{Cl}$, confidence interval; IV, inverse variance. A full color version of this figure is available at the Hypertension Research journal online.

$<0.00001$; Figure 6a; MD of diastolic BP, $-1.13 \mathrm{~mm} \mathrm{Hg}$; 95\% CI, -2.09 to $-0.17 \mathrm{~mm} \mathrm{Hg} ; P$ for effect $=0.02, P$ for heterogeneity $<0.00001$; Figure 6b).

\section{DISCUSSION}

The results of our analysis suggest that telmisartan therapy may reduce ambulatory BP (by 2.09/1.57 $\mathrm{mm} \mathrm{Hg}$ for 24-h, 2.96/2.15 mm $\mathrm{Hg}$ for last 6-h, 2.71/2.37 $\mathrm{mm} \mathrm{Hg}$ for morning, $1.74 / 1.73 \mathrm{~mm} \mathrm{Hg}$ for daytime and $2.70 / 2.08 \mathrm{~mm} \mathrm{Hg}$ for nighttime $\mathrm{BP}$ ) relative to losartan therapy in patients with hypertension. A previous meta-analysis (indirect comparisons) including data from 1556 patients has demonstrated that $80 \mathrm{mg}$ telmisartan exhibits the greatest efficacy, producing significantly $(P<0.0125)$ greater reductions in $24-\mathrm{h}$ systolic BP $(-12.4 \mathrm{~mm} \mathrm{Hg})$ than $50 \mathrm{mg}$ losartan $(-8.2 \mathrm{~mm} \mathrm{Hg})$, $80 \mathrm{mg}$ valsartan $(-8.9 \mathrm{~mm} \mathrm{Hg})$ or $40 \mathrm{mg}$ telmisartan $(-9.9 \mathrm{~mm} \mathrm{Hg})$, and in 24-h diastolic BP $(-7.9 \mathrm{~mm} \mathrm{Hg})$ than $50 \mathrm{mg}$ losartan $(-5.1 \mathrm{~mm} \mathrm{Hg})$ or $80 \mathrm{mg}$ valsartan $(-5.5 \mathrm{~mm} \mathrm{Hg}){ }^{19}$ A recent metaanalysis $^{3}$ combining results of only three or four RCTs revealed a significant reduction in $\mathrm{BP}$ for the last 6-h (MD for systolic $\mathrm{BP}$, $-2.56 \mathrm{~mm} \mathrm{Hg} ; 95 \% \mathrm{CI},-4.02$ to $-1.10 \mathrm{~mm} \mathrm{Hg} ; P=0.0006$; $\mathrm{MD}$ for diastolic BP, -2.39 95\% CI, -4.13 to $-0.66 \mathrm{~mm} \mathrm{Hg} ; P=0.007)$, 24-h (MD for systolic BP, $-2.47 \mathrm{~mm} \mathrm{Hg}$; $95 \% \mathrm{CI},-4.55$ to $-0.40 \mathrm{~mm} \mathrm{Hg}$; $P=0.02$; MD for diastolic BP, $-2.49 \mathrm{~mm} \mathrm{Hg} ; 95 \% \mathrm{CI},-4.42$ to $-0.56 \mathrm{~mm} \mathrm{Hg} ; \quad P=0.01$ ), daytime (MD for systolic $\mathrm{BP}$, $3.22 \mathrm{~mm} \mathrm{Hg}$; 95\% CI, -5.11 to $-1.34 \mathrm{~mm} \mathrm{Hg} ; P=0.0008$; $\mathrm{MD}$ for diastolic BP, $-2.18 \mathrm{~mm} \mathrm{Hg}$; 95\% CI, -3.78 to $-0.57 \mathrm{~mm} \mathrm{Hg} ; P=0.008$ ) and nighttime periods (MD for systolic BP, $-2.16 \mathrm{~mm} \mathrm{Hg}$; 95\% CI, -4.27 to $-0.06 \mathrm{~mm} \mathrm{Hg}$; $P=0.04$; MD for diastolic BP, $-2.24 \mathrm{~mm} \mathrm{Hg}$; $95 \% \mathrm{CI},-4.34$ to $-0.14 \mathrm{~mm} \mathrm{Hg} ; P=0.04$ ) with telmisartan in direct comparison with losartan. The present meta-analysis is more comprehensive, including data on 2409 patients with hypertension randomized to therapy with telmisartan or losartan from nine trials. We recently performed the most exhaustive meta-analysis ${ }^{20}$ of 50 RCTs (enrolling a total of 10494 patients) of telmisartan versus other angiotensin II type 1 receptor blocker therapy for the reduction of 'clinic' (not 'ambulatory') BP. In its sub-analysis of 22 RCTs including 3983 patients, telmisartan therapy significantly reduced both systolic and diastolic 'clinic' BP over losartan therapy (MD for systolic $\mathrm{BP},-3.17 \mathrm{~mm} \mathrm{Hg}$; $95 \% \mathrm{CI},-3.98$ to $-2.35 \mathrm{~mm} \mathrm{Hg}$; $P<0.00001$; MD for diastolic BP, $-1.83 \mathrm{~mm} \mathrm{Hg} ; 95 \% \mathrm{CI},-2.63$ to $-1.04 \mathrm{mmHg} ; \quad P<0.00001)$. These results of our previous metaanalysis $^{20}$ for 'clinic' BP may strengthen the findings of the present meta-analysis for 'ambulatory' BP.

The circadian variation in BP, which occurs in most individuals, is well known, with a steep rise in BP during the early morning hours. ${ }^{21}$ This coincides with the time of day when there is an increase in the risk of cardiovascular events. The incidence of cardiovascular complications is directly related to the systolic BP on arising. ${ }^{22}$ Extrapolation of these observations would suggest that antihypertensive therapy should provide BP control throughout the dosing interval. ${ }^{12}$ With a drug that is taken once daily in the morning, as telmisartan and losartan usually are, the end of the dosing interval is thus a critical period because it coincides with the period of increased cardiovascular vulnerability. ${ }^{23} \mathrm{~A}$ drug that is more able to sustain its anti-hypertensive effect during the early morning period should, therefore, be advantageous and may confer protection against cardiovascular events. ${ }^{12}$ Because the present metaanalysis did not evaluate the incidence of cardiovascular or cerebrovascular events and of mortality from such events, some caution should be needed in interpretation of the results. 


\begin{tabular}{|c|c|c|c|c|c|}
\hline $\begin{array}{l}\text { a } \\
\text { Study or Subgroup }\end{array}$ & Weight & $\begin{array}{l}\text { Mean Difference } \\
\text { IV, Random, } 95 \% \text { CI }\end{array}$ & & $\begin{array}{r}\text { Mean Di } \\
\text { IV, Randor }\end{array}$ & $\begin{array}{l}\text { ifference } \\
\mathrm{m}, 95 \% \mathrm{Cl}\end{array}$ \\
\hline Calvo 2004 & $4.5 \%$ & $7.80[3.35,12.25]$ & & & $\longrightarrow$ \\
\hline Ding 2004 & $3.5 \%$ & $-3.35[-8.80,2.10]$ & & & \\
\hline Fogari 2002 & $10.7 \%$ & $0.70[-0.24,1.64]$ & & & 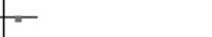 \\
\hline Lacourcière 2003,40 mg & $8.8 \%$ & $-2.05[-4.00,-0.10]$ & & & \\
\hline Lacourcière $2003,80 \mathrm{mg}$ & $8.8 \%$ & $-3.45[-5.40,-1.50]$ & & & \\
\hline Lacourcière 2004 & $10.2 \%$ & $-2.00[-3.23,-0.77]$ & & & \\
\hline Littlejohn 2000 & $8.3 \%$ & $-3.00[-5.22,-0.78]$ & & & \\
\hline Mallion $1999,40 \mathrm{mg}$ & $5.7 \%$ & $-3.50[-7.10,0.10]$ & & & \\
\hline Mallion $1999,80 \mathrm{mg}$ & $5.7 \%$ & $-5.30[-8.90,-1.70]$ & & & \\
\hline Masuda 2009 & $3.0 \%$ & $-3.00[-8.96,2.96]$ & & & \\
\hline Minami 2009 & $2.7 \%$ & $2.30[-4.23,8.83]$ & & & \\
\hline Neutel $2005,40 \mathrm{mg}$ & $9.4 \%$ & $-1.70[-3.35,-0.05]$ & & & \\
\hline Neutel $2005,80 \mathrm{mg}$ & $8.8 \%$ & $-3.50[-5.49,-1.51]$ & & & \\
\hline Smith 2003 & $9.8 \%$ & $-1.05[-2.50,0.40]$ & & & \\
\hline Total $(95 \% \mathrm{Cl})$ & $100.0 \%$ & $-1.73[-2.94,-0.52]$ & & & \\
\hline $\begin{array}{l}\text { Heterogeneity: } \mathrm{Tau}^{2}=3.34 \\
\text { Test for overall effect: } Z=\end{array}$ & $\begin{array}{l}\mathrm{Chi}^{2}=55 \\
80(\mathrm{P}=0\end{array}$ & $\begin{array}{l}5.52, d f=13(P<0.00001) ; I^{2}=77 \% \\
0.005)\end{array}$ & $\begin{array}{l}\stackrel{\vdash}{-10} \\
\text { Favour }\end{array}$ & $\begin{array}{l}-5 \\
\text { s telmisartan }\end{array}$ & $\begin{array}{l}1 \\
0 \\
\text { Favours losartan }\end{array}$ \\
\hline b $_{\text {Study or Subgroup }}$ & Weight & $\begin{array}{l}\text { Mean Difference } \\
\text { IV, Random, } 95 \% \mathrm{CI}\end{array}$ & & $\begin{array}{r}\text { Mean Di } \\
\text { IV, Randor }\end{array}$ & $\begin{array}{l}\text { ifference } \\
\mathrm{m}, 95 \% \mathrm{Cl}\end{array}$ \\
\hline Calvo 2004 & $5.3 \%$ & $3.70[0.84,6.56]$ & & & \\
\hline Ding 2004 & $4.5 \%$ & $-4.20[-7.50,-0.90]$ & & & \\
\hline Fogari 2002 & $9.0 \%$ & $-0.10[-1.04,0.84]$ & & & - \\
\hline Fogari 2002 vs valsartan & $9.0 \%$ & $1.70[0.76,2.64]$ & & & 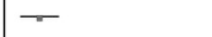 \\
\hline Lacourcière 2003,40 mg & $8.9 \%$ & $-1.30[-2.30,-0.30]$ & & & \\
\hline Lacourcière $2003,80 \mathrm{mg}$ & $8.3 \%$ & $-2.30[-3.60,-1.00]$ & & & \\
\hline Littlejohn 2000 & $8.2 \%$ & $-2.60[-3.99,-1.21]$ & & & \\
\hline Mallion $1999,40 \mathrm{mg}$ & $6.4 \%$ & $-2.50[-4.72,-0.28]$ & & & \\
\hline Mallion 1999, $80 \mathrm{mg}$ & $6.4 \%$ & $-3.50[-5.72,-1.28]$ & & & \\
\hline Masuda 2009 & $5.8 \%$ & $1.00[-1.53,3.53]$ & & & \\
\hline Minami 2009 & $2.7 \%$ & $0.20[-4.79,5.19]$ & & & \\
\hline Neutel $2005,40 \mathrm{mg}$ & $8.6 \%$ & $-1.40[-2.54,-0.26]$ & & & \\
\hline Neutel $2005,80 \mathrm{mg}$ & $7.9 \%$ & $-3.00[-4.50,-1.50]$ & & & \\
\hline Smith 2003 & $8.9 \%$ & $-0.90[-1.90,0.10]$ & & & \\
\hline Total $(95 \% \mathrm{Cl})$ & $100.0 \%$ & $-1.13[-2.09,-0.17]$ & & & \\
\hline $\begin{array}{l}\text { Heterogeneity: } \mathrm{Tau}^{2}=2.4 \\
\text { Test for overall effect: } \mathrm{Z}=\end{array}$ & $\begin{array}{l}\mathrm{Chi}^{2}=7 \\
31(\mathrm{P}=0\end{array}$ & $\begin{array}{l}4.75, d f=13(P<0.00001) ; I^{2}=83 \% \\
0.02)\end{array}$ & $\mathfrak{-}_{-1}$ & $\begin{array}{l}-5 \\
\text { teln }\end{array}$ & 0 \\
\hline
\end{tabular}

Figure 6 Forest plot of 24-h systolic (a) and diastolic (b) blood pressure among patients with hypertension randomized to telmisartan versus losartan or valsartan therapy. $\mathrm{Cl}$, confidence interval; IV, inverse variance. A full color version of this figure is available at the Hypertension Research journal online.

The findings of our sensitivity analysis suggest that between-study heterogeneity may be due to quasi-randomized crossover design studies. In addition to the parallel group studies, the use of doubleblind two-period or multiple period crossover designs can provide valid data for the dose finding of new antihypertensive drugs and their comparative evaluation. ${ }^{24}$ One or more control times are supplied by each of the cases themselves, to control for confounding by constant characteristics and self-confounding between the trigger's acute and chronic effects. ${ }^{25}$ Reports of crossover trials, however, frequently omit important methodological issues in design, analysis and presentation. ${ }^{26}$ The CONSORT (Consolidated Standards of Reporting Trials) reporting guidelines ${ }^{27}$ have not been extended specifically for crossover trials as yet. Guidelines for the conduct and reporting of crossover trials might improve the conduct and reporting of studies using this important trial design. ${ }^{26}$ Exclusion of the three quasi-randomized crossover design studies ${ }^{6,9,10}$ from the primary analysis for 24-h BP resulted in no between-study heterogeneity and did not substantively alter the results. The notable difference between the trials was the methodological quality score ${ }^{14}$ of the included studies: $0-1$, three trials; ${ }^{9-11} 2-3$, four trials; $;, 7,12,134$, two trials. ${ }^{5,8}$ Although eliminating the three low quality-score ( 0 or 1$)$ studies $^{9-11}$ from the primary analysis for 24-h BP did not substantially change the pooled point estimates, there was still statistically significant between-study heterogeneity. Thus, methodological quality of the trials may not contribute to between-study heterogeneity of results.
Our analysis must be viewed in the context of its limitations. First, we used only data from RCTs. Patients enrolled in RCTs may not be representative of patients typically seen in clinical practice. However, because RCTs balance both known and unknown confounders across treatment groups, this is the study design least vulnerable to bias. Second, our results may be influenced by a publication bias favoring telmisartan that was marketed later than losartan. This risk was minimized through an exhaustive search of the available literature. Third, we used the random-effects rather than fixed-effects estimate as the summary measure. In order to calculate a CI for a fixed-effects meta-analysis, the assumption is made that the true effect of intervention (in both magnitude and direction) is the same value in every study (that is, fixed across studies), which implies that the observed differences among study results are due solely to the play of chance, that is, that there is no statistical heterogeneity. ${ }^{28}$ When there is heterogeneity that cannot readily be explained, one analytical approach is to incorporate it into a random-effects model. For any particular set of studies in which heterogeneity is present, a CI around the random-effects pooled estimate is wider than a CI around a fixedeffect pooled estimate. ${ }^{28}$ To make a more conservative evaluation, we used the random-effects rather than fixed-effects model despite the presence or absence of between-study heterogeneity of results by means of standard $\chi^{2}$-tests.

\section{CONFLICT OF INTEREST}

The authors declare no conflict of interest. 
1 Krause T, Lovibond K, Caulfield M, McCormack T, Williams B, Guideline Development Group. Management of hypertension: summary of NICE guidance. BMJ 2011; 343 d4891.

2 Burnier M. Angiotensin II type 1 receptor blockers. Circulation 2001; 103: 904-912.

3 Xi GL, Cheng JW, Lu GC. Meta-analysis of randomized controlled trials comparing telmisartan with losartan in the treatment of patients with hypertension. Am J Hypertens 2008; 21: 546-552.

4 Higgins JP, Deeks JJ and Altman DG. Special topics in statistics. In Cochrane Handbook for Systematic Reviews of Interventions Version 5.1.0 (updated March 2011) (Higgins JPT and Green S eds) Chapter 16. The Cochrane Collaboration, 2011, Available from http://www.cochrane-handbook.org.

5 Ding PY, Chu KM, Chiang HT, Shu KH. A double-blind ambulatory blood pressure monitoring study of the efficacy and tolerability of once-daily telmisartan $40 \mathrm{mg}$ in comparison with losartan $50 \mathrm{mg}$ in the treatment of mild-to-moderate hypertension in Taiwanese patients. Int J Clin Pract 2004; 58 (Suppl 145), 16-22.

6 Fogari R, Mugellini A, Zoppi A, Derosa G, Rinaldi A, Fogari E, Vanasia A, Preti P. Efficacy of losartan, valsartan, and telmisartan in patients with mild to moderate hypertension: a double-blind, placebo-controlled, crossover study using ambulatory blood pressure monitoring. Curr Ther Res Clin Exp 2002; 63: 1-14.

7 Lacourcière Y, Gil-Extremera B, Mueller O, Byrne M, Williams L. Efficacy and tolerability of fixed-dose combinations of telmisartan plus HCTZ compared with losartan plus HCTZ in patients with essential hypertension. Int J Clin Pract 2003; 57: 273-279.

8 Mallion J, Siche J, Lacourcière Y. ABPM comparison of the antihypertensive profiles of the selective angiotensin II receptor antagonists telmisartan and losartan in patients with mild-to-moderate hypertension. J Hum Hypertens 1999; 13: 657-664.

9 Masuda S, Tamura K, Wakui H, Kanaoka T, Ohsawa M, Maeda A, Dejima T, Yanagi M, Azuma K, Umemura S. Effects of angiotensin II type 1 receptor blocker on ambulatory blood pressure variability in hypertensive patients with overt diabetic nephropathy. Hypertens Res 2009; 32: 950-955.

10 Minami J, Furukata S, Ishimitsu T, Matsuoka H. Comparison of therapies between fixed-dose telmisartan/hydrochlorothiazide and losartan/hydrochlorothiazide in patients with mild to moderate hypertension. Int Heart J 2009; 50: 85-93.

11 Neutel JM, Littlejohn TW, Chrysant SG, Singh A, Telmisartan Study Group. Telmisartan/ hydrochlorothiazide in comparison with losartan/hydrochlorothiazide in managing patients with mild-to-moderate hypertension. Hypertens Res 2005; 28: 555-563.

12 Smith DH, Cramer MJ, Neutel JM, Hettiarachchi R, Koval S. Comparison of telmisartan versus losartan: meta-analysis of titration-to-response studies. Blood Press Monit 2003; 8: 111-117.

13 Vitale C, Mercuro G, Castiglioni C, Cornoldi A, Tulli A, Fini M, Volterrani M, Rosano GM. Metabolic effect of telmisartan and losartan in hypertensive patients with metabolic syndrome. Cardiovasc Diabetol 2005; 4: 6 .

14 Jadad AR, Moore RA, Carroll D, Jenkinson C, Reynolds DJ, Gavaghan DJ, McQuay HJ. Assessing the quality of reports of randomized clinical trials: is blinding necessary? Control Clin Trials 1996; 17: 1-12.
15 Calvo C, Hermida RC, Ayala DE, Ruilope LM. Effects of telmisartan $80 \mathrm{mg}$ and valsartan $160 \mathrm{mg}$ on ambulatory blood pressure in patients with essential hypertension. J Hypertens 2004; 22: 837-846.

16 Lacourcière Y, Krzesinski JM, White WB, Davidai G, Schumacher H. Sustained antihypertensive activity of telmisartan compared with valsartan. Blood Press Monit 2004; 9: 203-210.

17 Littlejohn T, Mroczek W, Marbury T, VanderMaelen CP, Dubiel RF. A prospective, randomized, open-label trial comparing telmisartan $80 \mathrm{mg}$ with valsartan $80 \mathrm{mg}$ in patients with mild to moderate hypertension using ambulatory blood pressure monitoring. Can J Cardiol 2000; 16: 1123-1132.

18 Sharma AM, Davidson J, Koval S, Lacourcière Y. Telmisartan/hydrochlorothiazide versus valsartan/hydrochlorothiazide in obese hypertensive patients with type 2 diabetes: the SMOOTH study. Cardiovasc Diabetol 2007; 6: 28.

19 Neutel J, Smith DH. Evaluation of angiotensin II receptor blockers for 24-hour blood pressure control: meta-analysis of a clinical database. J Clin Hypertens (Greenwich) 2003; 5: 58-63.

20 Takagi H, Mizuno Y, Goto SN, Umemoto T, for ALICE (All-Literature Investigation of Cardiovascular Evidence) Group. Overview of telmisartan for blood pressure reduction among angiotensin II receptor blockers: a meta-analysis of head-to-head randomized trials. Int J Cardiol (e-pub ahead of print 5 December 2012; doi:10.1016/ jijcard.2012.11.086)

21 Neutel JM, Smith DH. The circadian pattern of blood pressure: cardiovascular risk and therapeutic opportunities. Curr Opin Nephrol Hypertens 1997; 6: 250-256.

22 Gosse P, Cipriano C, Bemurat L, Mas D, Lemétayer P, N'Tela G, Clementy J. Prognostic significance of blood pressure measured on rising. J Hum Hypertens 2001; 15: 413-417.

23 Muller JE, Stone PH, Turi ZG, Rutherford JD, Czeisler CA, Parker C, Poole WK, Passamani $E$, Roberts $R$, Robertson $T$, Sobel BE, Willerson JT, Braunwald EMILIS Study Group. Circadian variation in the frequency of onset of acute myocardial infarction. N Engl J Med 1985; 313: 1315-1322.

24 Ménard J, Bellet M, Serrurier D. From the parallel group design to the crossover design, and from the group approach to the individual approach. Am J Hypertens 1990; 3 815-819.

25 Maclure M, Mittleman MA. Should we use a case-crossover design? Annu Rev Public Health 2000; 21: 193-221.

26 Mills EJ, Chan AW, Wu P, Vail A, Guyatt GH, Altman DG. Design, analysis, and presentation of crossover trials. Trials 2009; 10: 27.

27 Altman DG, Schulz KF, Moher D, Egger M, Davidoff F, Elbourne D, Gøtzsche PC, Lang T, CONSORT GROUP. (Consolidated Standards of Reporting Trials). The revised CONSORT statement for reporting randomized trials: explanation and elaboration. Ann Intern Med 2001; 134: 663-694.

28 Deeks JJ, Higgins JP and Altman DG (eds)Analysing data and undertaking metaanalyses. In: Higgins JP and Green S (eds) Cochrane Handbook for Systematic Reviews of Interventions Version 5.1.0 (updated March 2011) Chapter 9. The Cochrane Collaboration, 2011, available from http://www.cochrane-handbook.org 